\title{
Private and Public Financial Mechanisms in the Greek Renewable Industry
}

\author{
Ioannis Kinias and Nikolaos Konstantopoulos
}

\begin{abstract}
The role of funding is crucial in the implementation of any business plan. The sources may vary depending on the business sector or its size and they can be categorized as internal and external sources, including the equity, the debt funds, the grants and the investment funds.

This paper examines the available financial mechanisms in the sector of Renewable Energy Sources (RES) in Greece. In this research, we investigate all the possible ways for funding in different renewable technologies and different size of enterprises. We present the process of the public subsidies either in the investment capital or in the selling price of the produced energy. We also investigate the role that the banking system plays and finally the existence of other mature ways of financing. The main scope of this paper is the research concerning the importance and the effectiveness of all these mechanisms.

With respect to research methodology, we realized a primary research in a very wide population in the business sector of RES, including enterprises from different renewable technologies and with different financial needs.

The empirical results presents a dysfunctional environment, with deficiencies and dependencies that eventually creates financial gaps and finally hampers the entrepreneurial activity in the sector.
\end{abstract}

Index Terms-Renewable energy sources, financing, entrepreneurship.

\section{INTRODUCTION}

This paper aims to investigate the financial environment that supports the field of renewable energy. We tried to record all the possible ways and mechanisms of financing in the sector of RES. We evaluated the effectiveness and the importance of such tools and we identified any malfunctions and gaps in the track of financial support of this entrepreneurial sector.

The significance of this paper is based on the fact that this is the result of a primary research carried out into the industry and developed in all the technologies of renewable energy sources and in all sizes of businesses from very small businesses to multinational enterprises.

In the literature, many studies have been carried out concerning the sources of funding. The internal sources include personal funds of the entrepreneur or these he can draw from his environment. Deakins \& Freel [1], describe them as "3F" capital from the acronym of friends, family and founder. Additionally, in the internal sources we may classify

Manuscript received October 25, 2013; revised December 30, 2013.

Ioannis Kinias and Nikolaos Konstantopoulos are with the University of the Aegean, Department of Business Administration Mihalon 8, 82100, Chios, Greece (e-mail: ikinias@ba.aegean.gr, nconsta@aegean.gr). the undistributed profits of the business. Hurst \& Lusardi [2], underline that "the possibility of a business plan's implementation, increases as the entrepreneur's economic 'health'."

The external sources may include short-term bank loans, venture capitals, formal or informal investors, leasing or even subsidies and grants. The bank lending is the most common and by far the most important form of external financing for enterprises [3].

On the other hand, there is a mismatch in the demand for funds from businesses and the availability of respective funds in the financial institutions. These gaps, recognized by Macmillan and identified as "financial gap" [4]. Additionally, another problem of the bank lending is the proposal's evaluating process. Akerlof, [5] says that the "the proposal's evaluations is a decision-making under uncertainty and information asymmetry". Most of the studies recognize the difficulty of entrepreneurs to access the bank loans (Small Business Service, 2004). Especially, in the field of renewable energy, the banking sector applies a different policy, supporting investments with guaranteed loans, which in many cases have reduced lending rates relative to the rest of the business market.

The grants are an alternative form of external finance. Especially in the field of renewable energy, most countries adopt two basic ways to support the entrepreneurial activity. These methods are:

- The Investment Subsidy and

- The Guaranteed Fixed Price for the sale of the produced energy

The measure of the guaranteed fixed selling price of the produced electricity (Feed-in Tariff), give to the producers a fixed price per unit of energy (KWh), depending on the type of technology they use " [6]. By this way, the entrance of smaller investors in this market becomes easier. The effectiveness of this measure depends on the level of feed-in. A very tempting price of energy can lead to an appreciable increase of producers and ultimately of the produced energy by this technology [7].

Many researchers examine the contribution of private equity (venture capital) and its role in the consolidation of new energy technologies [8]. In these studies they made a clear distinction between the professional and corporate venture capital. Regarding the professional venture capital, [9] note that its role can be catalytic in supporting the spread of renewable technologies. Other studies have investigated the role of corporate venture capital. In this case, specific schemes support business and actions in newly developed markets, betting on their particular expertise (know-how), that gain from their research in a specific field (knowledge - 
generating activities) [10]-[12]. The difference in the programs of corporate and professional associated with the targeting of the first to achieve not only economic but also strategic benefits of an investment activity [13]-[14].

There is an extensive literature on the role of finance as a factor of entrepreneurship. Especially, the very important issue of liquidity constraints as well as the business startup cost has also been investigated extensively in the literature. Fonseca [15] describe the significant differences in startup costs in different countries. Evans \& Jovanovich [16], highlight the importance of the entrepreneurs' ability to reach the necessary start-up capital for their business and Fonseca [15] notes "the interaction between the start-up costs and liquidity constraints affect the decision to become a businessman".

The contribution of this paper is the realization of a primary research and the investigation of all the available ways of funding in the Greek renewable industry.

These basic terms of financial mechanisms, startup costs and liquidity constraints will determine the scope of the study focused on the market of renewable energy sources. The rest of the paper is structured as below. The next section refers to the description of the data from the Greek renewable sector. Section III outlines the basic hypothesis. Section IV presents the methodological issues and Section $\mathrm{V}$ provides the empirical results. Finally, paper concludes by Section VI which refers to study's implications.

\section{THE CASE OF GREECE}

This section presents the financial framework for the RES project implementation, in Greece. This framework based on two main pillars. The first tool is the financial subsidize of the investment cost, either by national or European resources. The second mechanism is the guaranteed selling price of the produced electricity by RES, well known as Feed-in tariff. Concerning the tool of subsidies, specific European financial tools support a part of the investment cot of many projects. In this way, many RES projects with total budget of 1.061 billion $€$ performed by resources of European financial frameworks, till the end of 2004. These programs data are briefly presented in the Table I.

TABLE I: DATA FOR RES PROJECTS SUPPORTED BY EUROPEAN FINANCIAL

\begin{tabular}{|c|c|c|c|c|c|}
\hline \multicolumn{6}{|c|}{ FRAMEWORKS 2000-2004 } \\
\hline & $\begin{array}{l}\text { Wind } \\
\text { power }\end{array}$ & $\begin{array}{c}\text { Small } \\
\text { Hydro- } \\
\text { Electric }\end{array}$ & $\begin{array}{l}\text { Photo } \\
\text { voltaic }\end{array}$ & $\begin{array}{c}\text { Bio } \\
\text { mass }\end{array}$ & Total \\
\hline $\begin{array}{l}\text { Number of } \\
\text { projects }\end{array}$ & 50 & 31 & 69 & 5 & 155 \\
\hline $\begin{array}{l}\text { Total } \\
\text { Budget } \\
\text { (m. Euro) }\end{array}$ & 494 & 118 & 28 & 58 & 698 \\
\hline $\begin{array}{l}\text { Total } \\
\text { Public } \\
\text { Subsidy } \\
\text { (m. Euro) }\end{array}$ & 164 & 48 & 14 & 25 & 251 \\
\hline $\begin{array}{l}\text { Total } \\
\text { Electric } \\
\text { Power } \\
\text { (MW) }\end{array}$ & 501 & 86 & 3 & 39 & 629 \\
\hline $\begin{array}{l}\text { Annual } \\
\text { Energy } \\
\text { Production } \\
\text { (GWh) }\end{array}$ & 1.247 & 324 & 4 & 295 & 1.870 \\
\hline
\end{tabular}

Another European supporting mechanism, starting from 2004, through the national law 3299/2004, divided the Greek Territory into three zones and granted the $20 \%, 30 \%$ and $40 \%$ respectively of the total project cost including the cost of connection to the electricity grid.

On the other hand, the Feed-in tariff (FIT), is the most common tool in the European policy for renewable energy sources. The basic idea of this system is based on the mandatory purchase of the produced electricity. Richard [17] notes that "Feed-in tariff is a price driven incentive". Thus, the stability provided by a specific price, especially if it is high enough, can lead to continuous and strong growth of the market of renewable energy.

In Greece, the selling prices of the energy are fixed by laws and the sale contracts apply for a specific period of 20-25 years. Moreover, the prices are reviewed annually by decision of the competent Minister. The Table II presents the guaranteed selling prices by each technology, during the period of our research.

It is now clear, concerning the financial framework for the RES project implementation, that there is a very attractive business environment. This framework covers both an important part of the initial capital and also provides the guaranteed sale of all the generated electricity at a guaranteed price and for guaranteed period also.

\section{THEORETICAL HYPOTHESIS}

This section presents the theoretical hypothesis where on is based our quantitative research. These hypotheses cover all the possible ways of funding that described in the literature.

\section{A. The Role of the Governmental Financial Sources}

Grants are a very basic tool for the implementation of projects due to these is a significant percentage of the investment costs. Based on this observation, we arrive at the following hypothesis.

$\mathrm{H} 1$ : There is a positive correlation between the operational characteristics of the enterprise (size, age, technology) and the importance of governmental ways of financing (grants).

\section{B. The Role of the Equity Capital}

In this section, we study the correlation between the operational characteristics of the enterprises and the importance of existence additional own capital for the completion of the projects, given delays in the disbursement of subsidies. In this direction we make the following hypothesis.

$\mathrm{H} 2$ : There is a positive correlation between the operational characteristics of the enterprise (size, age, technology) and the use of own capitals for the completion of projects.

\section{Low Growth Expectations Due to "Financial Gap"}

In this section, we study the correlation between the operational characteristics of the enterprises and their ability to expand their activity in other renewable energy technologies. In this direction we make the following hypothesis.

H3: There is a negative correlation between the operational characteristics of enterprises (size, age, 
technology) and the inability of expansion into other renewables, due to the capital deficiency.

\begin{tabular}{|c|c|}
\hline & $\begin{array}{c}\text { Price of } \\
\text { Electricity } \\
\text { (Euro/MWh) }\end{array}$ \\
\hline \multicolumn{2}{|l|}{ Electricity Production from } \\
\hline $\begin{array}{l}\text { Wind power, Hydropower exploited in small } \\
\text { hydropower stations with installed capacity up to fifteen } \\
\text { (15) MW, Geothermal and Biomass units. }\end{array}$ & 87,84 \\
\hline Wind power from offshore wind parks & 104,84 \\
\hline $\begin{array}{l}\text { Solar energy utilized in photovoltaic units with } \\
\text { installed capacity less than or equal to one hundred } \\
\text { (100) } \mathrm{kW} \text {, which are installed on property ownership. }\end{array}$ & 454,73 \\
\hline $\begin{array}{l}\text { Solar energy utilized in photovoltaic units with } \\
\text { installed capacity more than one hundred }(100) \mathrm{kW} \text {. }\end{array}$ & 404,20 \\
\hline $\begin{array}{l}\text { Solar energy exploited in units with a different } \\
\text { technology than photovoltaic with an installed capacity } \\
\text { of up to five (5) MW. }\end{array}$ & 264,84 \\
\hline $\begin{array}{l}\text { Solar energy exploited in units with a different } \\
\text { technology than photovoltaic with an installed capacity } \\
\text { more than five (5) MW. }\end{array}$ & 244,84 \\
\hline Other RES (Geothermal and Biomass units etc.) & 87,84 \\
\hline
\end{tabular}

\section{The Role of Feed-in Tariff}

In this section, we study the correlation between the importance of the guaranteed selling price of energy as a key incentive for entrepreneurial activity as well as the possibility to interrupt the operation of the enterprise due to reduction of this guaranteed price. In this direction we make the following hypothesis.

$\mathrm{H} 4$ : There is a negative correlation between the operational characteristics of the enterprise (size, technology) and the importance of feed-in for its entrepreneurial activity.

\section{E. The Role of the Bank Lending}

In this section, we analyze the close correlation observed in the survey, between systematic delays in the disbursement of subsidies and the need of bank loans for the completion of projects. In this direction, we make the following hypothesis.

H5: There is a positive correlation between the delays in governmental ways of funding (grants) and the "shift" in bank lending.

\section{MethodologicAl Issues}

The methodological tool used to draw meaningful conclusions was primary research. Our survey was based on a questionnaire that collected information using descriptive questions (free text), multiple choice questions and questions using a Likert Scale. Our goal in designed research was the creation of a comprehensive questionnaire that could cover research purposes quickly.

The geographic dispersion of the quantitative research covers all of Greece. Consistent with the method of sampling at layers, the population is divided into homogeneous teams (layers) concerning certain characteristics; therefore, a small sample from each layer can account for the behaviour of the total population.

There are many different characteristics concerning the homogeneity of layers, such as geographic place, sex, age-related teams, etc. In this study, the characteristic for creating the sampling layers was the installed energy capacity by RES and the licensing process that the company followed.

In Greece, the law determines two different licensing procedures in the field of renewable energy sources and excludes certain productive units from certain stages of the licensing process; this discrimination finally leads to different technological choices for the companies. Therefore, we fix the following two groups for sampling:

- The companies that are obligated to obtain the energy production licence, which we define as the "team of the large investors".

- The companies that are excluded from the energy production licence, which we define as the "team of the small investors".

The sample selection was chosen from the total population of firms that had projects in operation in December 2009. From the team of large investors, there were 165 production units that were found in use at this time with a total installed capacity $1.068 \mathrm{MW}$; from the team of small investors, roughly 400 photovoltaic projects with total installed capacity $35 \mathrm{MW}$ were found.

For our research, we selected a sample of 80 firms, 40 from each group.

- The 40 companies from the first group own 108 energy-productive units (projects) with a total installed capacity of $920,40 \mathrm{MW}$, which corresponds to $86,2 \%$ of the total installed capacity in the country.

The 40 companies from the second group own 53 energy-productive units (projects) with a total installed capacity of $6,80 \mathrm{MW}$, which corresponds to $19,5 \%$ of the country's total installed capacity.

\section{EMPIRICAL RESULTS}

In this section, we present some general descriptive statistics concerning the entrepreneurial behavior of the enterprises that activated in the RES sector.

Concerning the preparation of their business plans more than $60 \%$ of enterprises made these studies by their own means, especially in larger companies that they had the necessary scientific expertise to carry out such projects.

Regarding the confirmation of these business plans, it is important that for $70 \%$ of companies of our survey the studies are confirmed during the implementation of the projects.

The research shows clearly that the main aim of investors was a guaranteed return on their investment, with a small or medium cost. There is not any sense of risk in their business 
logic and culture. It is important that for $90 \%$ of the investors, their investment paid off profit over $15 \%$ and this confirms their decisions to extend their activity in this sector by investing in new projects. It is also important that the main incentives, for motivation in the business field of RES, was the guaranteed unit price (feed-in tariff) with $85 \%$ and the grants for project implementation with $73.7 \%$.

The research also proves that more than $70 \%$ of companies found significant delays in the disbursement of subsidies. The result was the shift of investors in alternative funding sources, such as the extra bank debt at a rate of almost $70 \%$ and the use of equity in approximately $40 \%$.

So, the most important role in project implementation played by the bank lending in $85 \%$, followed by equity with $80 \%$ and end subsidies by $75 \%$. So, it is clear a strong association of the RES market with the financial institutions, concerning the completion of the investments.

Therefore, it becomes clear that the malfunctioning of institutional financing mechanisms can foreclose businesses that do not have high availability and additional equity and also that a dependent market from the banking system could collapse in a possible malfunction of the banking system. According to research results, the $76 \%$ of companies would consider the closure of the business if the feed-in tariff would be reduced.

\section{A. The Role of the Governmental Financial Sources}

It becomes clear that as greater become the total amount of investment, which is directly connected with the technology applied, much more necessary and important become the contribution of governmental funding for the implementation of projects.

It is also important the stability of these measures for a considerable period of time, as well as the existence of distinct procedures for their implementation. The need for these ways of funding decreases as the technologies applied maturing and the applied technologies become more familiar and usual in the business field.

We see, therefore, that almost the ideal theoretical framework concerning the subsidies miss from the entrepreneurial sector of RES in Greece. Especially the distinct processes are replaced by a problematic implementation, resulting in a financial gap in many business plans. So we conclude that a very important measure, which could be a growth indicator, create a dysfunction in the sector of renewable technologies.

\section{B. The Role of the Equity Capital}

The correlations prove that the larger and more established companies are able to disburse additional equity in order to address any funding gap created either by governmental dysfunction or potential inability of the banking system.

It is therefore confirmed the well-established theory which notes that the probability of a firm to proceed with the implementation of a business plan, increases as its financial "health".

On the other hand it is important that any malfunctioning of other pillars of funding, can lead to a market that will effectively exclude small and weak investors, creating an oligopolistic scheme which will control a very important commodity like energy (See Table III).

\begin{tabular}{|c|c|c|c|c|c|}
\hline \multicolumn{2}{|c|}{ Hypothesis } & Description & \multicolumn{3}{|c|}{ Variables } \\
\hline & & & $\begin{array}{l}\text { Group } \\
\text { (size) }\end{array}$ & $\begin{array}{c}\text { Establish } \\
\text {-Startup }\end{array}$ & $\begin{array}{c}\text { RES } \\
\text { technology }\end{array}$ \\
\hline \multirow[t]{2}{*}{ H1 } & \multirow{2}{*}{$\begin{array}{l}\text { Lack of } \\
\text { subsidies, } \\
\text { obstacle for } \\
\text { the } \\
\text { completion } \\
\text { of projects }\end{array}$} & $\begin{array}{l}\text { Pearson } \\
\text { Correlation }\end{array}$ &, $427^{* *}$ &, $306^{* *}$ &, $462^{* * *}$ \\
\hline & & $\begin{array}{l}\text { Sig. } \\
\text { (2-tailed) }\end{array}$ & ,000 & ,006 & ,000 \\
\hline \multirow[t]{2}{*}{ H2 } & \multirow{2}{*}{$\begin{array}{l}\text { Finalize the } \\
\text { implementati } \\
\text { on of projects } \\
\text { by own } \\
\text { capitals }\end{array}$} & $\begin{array}{l}\text { Pearson } \\
\text { Correlation }\end{array}$ &, $509^{* *}$ & $372^{* *}$ &, $514^{* *}$ \\
\hline & & $\begin{array}{l}\text { Sig. } \\
\text { (2-tailed) }\end{array}$ & ,000 & ,001 & ,000 \\
\hline
\end{tabular}

\begin{tabular}{|c|c|c|c|c|c|}
\hline \multirow[t]{2}{*}{ H3 } & \multirow{2}{*}{$\begin{array}{l}\text { No extending } \\
\text { to other RES } \\
\text { due to capital } \\
\text { deficiency }\end{array}$} & $\begin{array}{l}\text { Pearson } \\
\text { Correlation } \\
\end{array}$ &,$- 442^{* * *}$ &,$- 241^{*}$ &,$- 409^{* *}$ \\
\hline & & $\begin{array}{l}\text { Sig. } \\
\text { (2-tailed) }\end{array}$ & ,000 & ,039 & ,000 \\
\hline \multirow[t]{2}{*}{ H4 } & \multirow{2}{*}{$\begin{array}{l}\text { Closure in a } \\
\text { possible } \\
\text { reduction in } \\
\text { the } \\
\text { guaranteed } \\
\text { price (feed-in } \\
\text { tariff) }\end{array}$} & $\begin{array}{l}\text { Pearson } \\
\text { Correlation }\end{array}$ &,$- 334^{* *}$ & &,$- 453^{* *}$ \\
\hline & & $\begin{array}{l}\text { Sig. } \\
\text { (2-tailed) }\end{array}$ & ,002 & & ,000 \\
\hline
\end{tabular}

\begin{tabular}{|c|c|c|c|}
\hline \multirow{3}{*}{ H5 } & & & Delays in disbursement of subsidy \\
\hline & \multirow{2}{*}{$\begin{array}{l}\text { Finalize the } \\
\text { implementati } \\
\text { on of projects } \\
\text { by loans }\end{array}$} & $\begin{array}{l}\text { Pearson } \\
\text { Correlation }\end{array}$ & $478^{* *}$ \\
\hline & & $\begin{array}{l}\text { Sig. } \\
\text { (2-tailed) }\end{array}$ &, 000 \\
\hline & \multirow{2}{*}{$\begin{array}{l}\text { The role of } \\
\text { banking } \\
\text { lending }\end{array}$} & $\begin{array}{l}\text { Pearson } \\
\text { Correlation }\end{array}$ &, $690^{* *}$ \\
\hline & & $\begin{array}{l}\text { Sig. } \\
\text { (2-tailed) }\end{array}$ & ,000 \\
\hline & \multirow{2}{*}{$\begin{array}{l}\text { Lack of } \\
\text { banking } \\
\text { loans, } \\
\text { obstacle for } \\
\text { the } \\
\text { completion } \\
\text { of projects }\end{array}$} & $\begin{array}{l}\text { Pearson } \\
\text { Correlation }\end{array}$ &, $550^{* *}$ \\
\hline & & $\begin{array}{l}\text { Sig. } \\
\text { (2-tailed) }\end{array}$ & ,000 \\
\hline \multicolumn{4}{|c|}{$*$ : sig. $<5 \%$} \\
\hline
\end{tabular}

\section{Low Growth Expectations Due to "Financial Gap"}

From these correlations, becomes clear that as smaller and younger the firms are, more difficult becomes their activity in other technologies that require bigger financial resources.

There are many researchers [18], found that growth rates are inversely proportional to the size of the business. The result is that the correlation between firm size and growth, as well as the firm age and growth, is controversial in the European reality.

In this case, many firms can rely on their financial strength and exploit any financial gaps created by the business environment. According to this way they can apply a corporate venture capital policy, aiming not only to achieve economic but mainly strategic benefits, as reported by 
[19]-[20].

Therefore we observe large domestic business groups trying to expand them in the photovoltaic technology, through the enlargement of their market share, as well as the reduction of the risk in their investment portfolio. At the same time, international business groups have a corresponding investment activity in order to claim strategic advantage in the Greek RES market through the expansion of the geographical dispersion of their portfolio.

\section{The Role of Feed-in Tariff}

It becomes clear that the importance of the feed-in grows as firm size gets smaller. We can see a trend, even shutdown their business in case of reduction of the guaranteed price. This fact demonstrates clearly that the entrepreneurs are not satisfied with the value of their investment, but treat it as an investment product with significantly high efficiency.

This phenomenon does not appear in the enterprises of Group 2, since the selling price of energy is significantly lower. This means that the operators in this area are convinced of the value of their choice and the deal with the RES is a strategic choice for them.

The important conclusion we can draw from the above correlations is that after several years of implementation of this policy has not established a wealth business culture to the small investor. It is clear that finally that the investors have not understood the uniqueness of the natural resource of solar energy.

Greece is a privileged country in respect to sunshine annually, compared to all the other countries of Europe. Therefore, the photovoltaic technology should be the flagship of a strategy shift to clean energy, creating a different culture to the people.

\section{E. The Role of the Bank Lending}

From these correlations, becomes clear that as larger the problems and the delays are in the disbursement of subsidies, much greater becomes the need of support from the bank lending.

Undoubtedly, bank lending is the most common and by far the most important form of external financing for enterprises. Especially in the Greek business scene, it is confirmed the close relationship of Greek businesses with the banking sector in order to raise capital.

Especially in the field of renewable energy, the banking sector applies a special policy, supporting investments with guaranteed loans, which in many cases have reduced lending rates relative to the rest of the business market, as well as new targeted products related to Green Banking.

Nevertheless, according to research by the European Commission, nearly $90 \%$ of Greek entrepreneurs identify the inadequacy of funding as the most important factor that prevents the creation of a business.

In any case, the main outcome is that the dysfunction in the institutional forms of financing leads to a tight embrace of the business environment in the banking system. This can lead to a strong interaction form that can even reach the limits of reliance.

Especially today, the difficult times facing the international and the Greek economy, spearheaded the banking industry, every possible restriction of liquidity due to the crisis can undoubtedly lead to a reduction or reversal in the growth of the renewable industry.

\section{CONCLUSIONS}

Regarding the sources of funding should first mention the great importance of the tool of subsidies, especially for "small" businesses. Unfortunately, the implementation framework includes non-functional or problematic processes, resulting in systemic delays in the subsidies' disbursement. This leads to the creation of a funding gap and thus to the invalidated of the significance of a measure that could be a growth driver.

The important gap that creates the dysfunction of institutional forms of funding is the reason for the significant role that plays that bank lending. It is striking that its absence will be a deterrent for the vast majority of businesses. The result is a very strong connection of the entrepreneurship in the sector with the banking system. This powerful form of interaction, especially in difficult times facing the global economy and the banking industry, may lead to a reduction or reversal in the growth of the industry.

Furthermore, the survey results prove that the "larger" firms can more easily disburse additional private funds and address any funding gap. This confirms the theory that links the possibility of implementing a business plan to the financial soundness of a company.

It is important that in contrast to these financing tools we observe almost no other investment schemes that could provide a different boost in the sector's entrepreneurship.

Finally, we should not overlook the overall international economic and political conditions experienced by the country and the wider global community. It should be noted that in recent years the business is conducted in conditions of prolonged recession. This undoubtedly affects both the final decision on establishing new businesses and risk-taking. Moreover, these conditions also lead to the increasing difficulty in finding financial support for new business activities resulting in the freezing of many integrated operational plans.

\section{REFERENCES}

[1] Deakins and Freel, "Entrepreneurship," Kritiki, 2007.

[2] E. Hurst and A. Lusardi, "Liquidity constraints, household wealth, and entrepreneurship," The Journal of Political Economy, vol. 112, no. 2, pp. 319-347, April 2004.

[3] ESRC (ESRC Centre for Business Research), The State of British Enterprise, Department of Applied Economics, University of Cambridge, 2002.

[4] J. McMillan and C. Woodruff, "The central role of entrepreneurs in transition economies," Journal of Economic Perspectives, vol. 16, pp. 153-170, 2002.

[5] G. Akerlof, "Qualitative uncertainty and the market mechanism," Quarterly Journal of Economics, vol.89, pp. 488-500, 1970.

[6] G. Resch, M. Ragwitz, and A. Held, "Feed-in tariffs and quotas for renewable energy in Europe," CESifo, Report, 4/2007.

[7] N. Wohlgemuth and R. Madlener, "Financial support of renewable energy systems: investment vs operating cost subsidies," Proceedings of Norwegian Association for Energy Economies (NAEE), Norway, September 2000

[8] B. Moore and R. Wustenhagen, "Innovative and sustainable energy technologies: the role of venture capital," Business Strategy and the Environment, vol. 13, pp. 235-45, 2004. 
[9] J. Petty and M. Gruber, "In pursuit of the real deal: A longitudinal study of VC decision making," Journal of Business Venturing, vol. 26, no. 2, pp. 172-88, 2011.

[10] H. Chesbrough and C. Tucci, "Corporate venture capital in the context of corporate innovation," DRUID Summer Conference, Copenhagen, June 14-16, 2004, pp. 86-96.

[11] G. Dushnitsky and M. J. Lenox, "When do incumbents learn from entrepreneurial ventures? Corporate venture capital and investing firm innovation rates," Research Policy, vol. 34, no. 5, pp. 615-39, 2005.

[12] G. Dushnitsky and J. M. Shaver, "Limitations to inter-organizational knowledge acquisition: the paradox of corporate venture capital," Strategic Management Journal, vol. 30, no. 10, pp. 1045-1064, 2009.

[13] H. Chesbrough, "Making sense of corporate venture capital," Harvard Business Review, vol. 80, no. 3, pp. 90-99, 2002.

[14] V. Ivanov and R. Masulis, "Corporate venture capital, strategic alliances and the governance of newly public firms," University of Kansas Working Paper, 2007.

[15] R. Fonseca, P. C. Michaud, and T. Sopraseuth, "Entrepreneurship, wealthy, liquidity constraints and start-ups costs," EPEE, University of Evry, Discussion Paper, no. 2874, 2007.

[16] D. Evans and B. Jovanovic, "An estimated model of entrepreneurial choice under liquidity constraints," Journal of Political Economy, vol. 97, no. 4, pp. 808-827, 1989.

[17] R. E. Caves, "Industrial organization and mew findings on the turnover and mobility of firms," Journal of Economic Literature, vol. 36, no. 4 pp. 76-82, 1998.

[18] D. B. Audretsch, E. Santarelli, and M. Vivarelli, "Start-up size and industrial dynamics: some evidence from Italian manufacturing," International Journal of Industrial Organization, vol. 17, pp. 965-983, 1999.

[19] P. A. Geroski, "What do we know about entry," International Journal of Industrial Organization, vol. 13, no. 4, December 1995.

[20] D. Harhoff and K. Stahl, "Unternhemens-und Beschaeftigungsdynamik in West-deutschland: Zum Einfluww von Haftungsregeln und Eigentuemerstruktur," 1995.

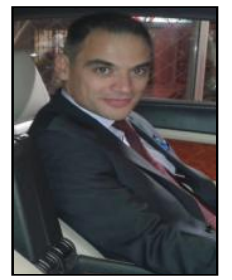

Ioannis Kinias is an adjunct lecturer of Business Administration, School of Management and Economics, University of the Aegean. He graduated from the Department of Mechanical Engineering of the Aristotle University of Thessaloniki, holds a master's degree (MSc) in Engineering Management from the Brunel University (UK) and a Ph.D. in Business Administration from the Department of Business Administration of the University of the Aegean. He has taught at undergraduate and postgraduate level in the University of Central Greece as well as in the University of the Aegean. His studies and articles have been published in various journals and edited volumes. His research interests are: Entrepreneurship, Energy Policy, Strategic Management, and Business Administration.

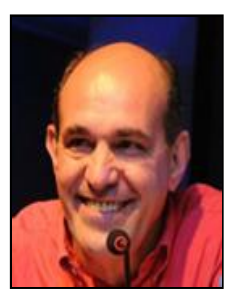

Nikolaos Konstantopoulos is an associate professor of Business Administration, School of Management and Economics, University of the Aegean. He graduated from the Department of Political Science and Public Administration of the University of Athens, Department of Psychology, University Clermont Ferrand II, holds a masters degree (DEA) in Management and Organizational Science from the University of Picardie (Amiens-France), (DEA) in communication studies, and Management of Speech and body language from the University «Paris Nord - Paris XIII» Villetaneuse, (DEA) in Sociology of businesses and organizations - Sociology of Work from the University Jules Verne. He has taught at undergraduate and postgraduate level in various Universities in Greece and abroad. It is member of scientific associations and reviewer for international journals. Studies and articles have been published in various journals and edited volumes. His research interests are: Management of small and medium enterprises, Entrepreneurship and Strategic Decisions, Corporate Communication and History of Greek Enterprises. 